\title{
A Rhetorical analysis of Philippians 1:27-2:18
}

A H Snyman

(University of the Free State)

\section{ABSTRACT}

\section{A Rhetorical analysis of Philippians 1:27-2:18}

A new trend in rhetorical analysis is to reconstruct Paul's rhetorical strategy from the text itself, rather than applying ancient or modern rhetorical models to his letters. A proposal for such a text-centred approach, in which the focus shifts from the formal to the functional, is briefly summarised in this article, followed by a discussion of the rhetorical situation that Paul wants to address in this letter. Spiritual problems, especially internal unrest and opposition from outside, called forth the letter. In order to address these problems, Paul tries to persuade his audience to persevere in living and proclaiming the gospel. This dominant rhetorical strategy of 1:27 - 2:18 can be divided into four phases: 1:27-30 (exhorting the Philippians to persevere in proclaiming the gospel); 2:1-11 (exhorting them to persevere in living the gospel); 2:12-13 (exhorting them to persevere in living the gospel), and 2:14-18 (exhorting them to persevere in proclaiming the gospel).

In order to persuade his audience, Paul uses various rhetorical strategies and techniques. In analyzing these, the focus is on exegetical issues with rhetorical impact, on the types of arguments used, on the way Paul argues and on the rhetorical techniques used to enhance the impact of his communication. I hope to prove that Paul's persuasive strategy in Philippians could be constructed fairly accurately from the text itself, provided that it is read carefully and systematically.

\section{INTRODUCTION}

In reaction to the way in which Betz (1979) and his colleagues (like Watson 1988 and 1997 in the case of Philippians) chose rhetorical models from outside to analyze New Testament texts, scholars started moving towards a reconstruction of Paul's rhetorical strategy from the text itself. Examples of this new trend are the works of Kern (1998) on Galatians and Anderson (1999) on Galatians 1-5:12, Romans 1:1-11 and 1 Corinthians. A recent proposal for such a textcentred approach to rhetorical analysis is the publication of Tolmie Persuading the Galatians (2005) in the WUNT series. The proposal 
deserves the attention of all scholars interested in the rhetorical analysis of NT texts and will serve as the framework of this article.

In the first chapter Tolmie (2005:27-30) explains the approach he followed in analyzing the letter to the Galatians. After constructing the rhetorical situation, that is, the broad outline of what Paul wants to achieve in the letter as a whole, he formulates his "minimal theoretical framework", consisting of the following aspects:

- The identification of the dominant rhetorical strategy in a particular section by answering two questions: How can one describe Paul's primary rhetorical objective in the section?; and: How does he attempt to achieve this objective?

- The analysis of the section by focussing on the type of arguments Paul uses and why they are effective, or by describing the way he argues to persuade his audience. Exegetical issues are discussed, especially when there is not agreement on the meaning of a specific phrase or expression of rhetorical significance.

- The identification of the rhetorical techniques used to enhance the impact of his communication.

- A description of the way in which the argument in the letter as a whole has been organized. Of course, this aspect can only be addressed once the analysis of the whole letter has been completed (For a detailed exposition of his proposal, see Tolmie 2000:122-123 and 2005:27-30).

The purpose of this article is to analyze Philippians 1:27-2:18 in terms of Tolmie's proposal for rhetorical analysis. I hope to prove that Paul's rhetorical strategy in this section can be reconstructed fairly accurately from the text itself, provided that one reads the text carefully and systematically. My assumption is that it is not necessary to force rhetorical models from outside on the text in order to understand Paul's persuasive strategy in Philippians.

\section{THE RHETORICAL SITUATION OF THE LETTER}

According to commentators like Hendriksen (1961:9-20), Müller (1976:13-14) and Matter (1976:11) the situation that called forth the letter was the gift that Paul received from the Philippians through their emissary Epaphroditus. The gift was a clear sign of the deep personal relationship between Paul and the church in Philippi, and 
Marshall (1987:35-69) and Brown (1997:486) regard the maintenance of this friendship as the main motivation for the letter.

That the letter has undertones of friendship is clear from its very beginning $(1: 3-4,7,8)$, as well as from the personal way in which Paul addresses his audience as "my brothers" (1:12; $3: 1,13,17 ; 4: 1,8$ ) and "my dear friends" (a ga pht oi vmou in 2:12). In his construction of the situation in Philippi, however, Silva (1988:21) comes to a different conclusion. He argues "that the Philippians were facing great adversity, had lost their sense of Christian joy and were tempted to abandon their struggle". The believers in Philippi were experiencing a lack of unity and many of them had lost their confidence in maintaining their Christian confession. Consequently, Paul responded by persuading them to stand fast and to persevere (For a detailed description of the context of the letter, see Silva 1988:1-10).

O'Brien (1991:36-38) and Fee (1995:32) are in agreement with Silva's focus on the situation in Philippi. Fee (1995:29), for example, finds the occasion of the letter in both frienship and its "hortatory sections", which are case-specific to the situation in Philippi. The reason for the exhortations is the suffering of the Philippians as the result of opposition and especially the internal unrest, on which he remarks: "The Philippians are in a life-and-death struggle for the gospel in Philippi, and if their present unrest goes uncorrected, it could bid fair to blunt, if not destroy, their witness to Christ in their city. There can be little question that this issue lies behind the major moments in the letter" (Fee 1995:32. Italics mine).

I find this construction of the situation convincing, since it covers various aspects of the church life in Philippi. The letter must be seen as a response to the problems in Philippi - that Macedonian city to which Paul refers as constituting "the beginning of the gospel" $(4: 15)$. Therefore he wrote the letter to persuade his fellowChristians, with whom he had a deep personal relationship, to persevere in proclaiming and living the gospel that they received at the founding of the church in Philippi.

The rest of the article will be devoted to a text-centred analysis of the way in which Paul attempts to persuade his audience in 1:27$2: 18$. 


\section{ANALYSIS OF PHILIPPIANS 1:27-2:18}

\subsection{Introduction}

Before discussing Paul's persuasive strategy in this section, it is necessary to attend to the following issues:

Philippians 1:27-2:18 is demarcated by rhetorical considerations. In the previous section $(1: 12-26)$ Paul reassures the Philippians that his imprisonment and possible execution are for the advancement of the gospel. In 1:27-2:18 he proceeds by giving them some practical exhortations: he urges them to stand firm and to fight together for the sake of the gospel (1:27-30), to be united, thereby making him completely happy $(2: 1-11)$, to work out their own salvation (2:12-13) and to shine as lights in the world by holding out the word of life $(2: 14-18)$. These exhortations end at $2: 18$. The next section (2:19-30) deals with the three "comings" from Rome to Philippi (as Fee 1995:251 puts it): Epaphroditus's now, Timothy's very soon and his own as soon as possible.

Exhortations like these in $1: 27 ; 2: 2-4,12,14$ and 18 are based on the assumption that a special relationship exists between Paul and the Philippians. The apostle must have thought that the relationship between them was so strong that he could rely on the fact that they would do what he requires, that they would try their best not to disappoint him, in short: that they would behave in a way consistent with their relationship. The maintenance of this relationship was of paramount importance to both Paul and the Philippians.

The section 1:27-2:18 could be divided into four phases, based on shifts /trends in his argument. They are as follows:

1:27-30 (Proclaiming the gospel).

2:1-11 (Living the gospel).

2:12-13 (Living the gospel).

2:14-18 (Proclaiming the gospel).

These distinctive phases will be motivated in the analysis below. They imply that there are some external pressures, as well as internal unrest, which make the situation of the church in Philippi tenuous. Paul's main concern for the Philippians is directly related to the progress of the gospel (as is the case in the previous section, 1:1226). He sincerely hopes that their friendship, and especially their participation in the gospel, will help them to overcome this twofold 
crisis (Fee 1995:161). This is why the phases have so many supportive arguments, not only from past achievement, but also from the Philippians' spiritual experiences, from divine involvement and from example.

\subsection{Philippians 1:27-30: Exhorting the Philippians to persevere in proclaiming the Gospel}

In the previous section (1:12-26) Paul had given the Philippians a word of assurance: everything that had happened to him was for the advancement of the gospel. However, there is one thing that perturbs the apostle, as is clear from this phase of his argument: (Literally) "Only (monon) continue to exercise your citizenship (pol it eues qe) in a manner worthy of the gospel of Christ, that whether I come and see you or am absent, I may hear that you are standing firm (s thkete) with one spirit (ej ehi; pneumati), with one soul (mia) y uch) striving side by side (s unaqlount e $)$ for the faith of the gospel, and not frightened (mh; pturomenoi) in anything by the adversaries, which is for them a clear sign of destruction, but of your salvation, and this from God (ka i ; out o a p 0;qeou)" (1:27-28).

In his commentary Silva (1988:91-93) makes some remarks on these two verses, which address the rhetorical situation in a very special way. According to him, the verb ( $p$ ol it eues qe) reminds the audience that their responsibility is "a permanent obligation that requires the fundamental virtue of perseverance" (1988:91). The importance of perseverance as a virtue is clear from the force of the following expressions:

i) The Christian behaviour of the Philippians must continue "whether I come and see you or am absent" (1:27). This means that the Philippians must be consistent in their witness, regardless of their circumstances. Paul's absence did not justify a relaxing of their Christian duties. "Perseverance does not admit of interruptions" (Silva 1988:91).

ii) The verbs that Paul uses stress the importance of spiritual tenacity: st hket e, which suggests firmness and steadfastness, and sunaqlounte $\sim$, which indicates that Christian citizenship requires conscious effort, because it consists in a struggle.

iii) In order to persevere the Philippians need uninamity. The prefix sun- in sunaqlount $e \sim$ already suggests a joint struggle, and this thought is expressed in a command that is made even more forceful by the chiastic pattern in 1:27: 


\section{Asthkete \\ B ej ehi;p neumat $\mathrm{i}$ \\ B mialy uch/ \\ A s unaqlount e}

This command is further developed in 2:1-4 and alerts us to the fact that the struggle of the Christian citizen takes place within the believing community. It is not an individualistic exercise.

iv) In 1:28 Paul refers to spiritual opponents (ajt ikeimenwn) who try to intimidate the Philippians. (Silva is of the opinion that the reference is to the Judaizers, while the majority of exegetes regard the opponents as from the pagan environment.) The reference to opponents suggests that the struggle is real and likely to intimidate the Philippians.

Louw and Nida (1988:508) define the main verb p ol it eues qe as "to conduct oneself with proper reference to one's obligations in relationship to others, as part of some community - 'to live, to conduct one's life, to live in relationship with others"". In this context the conduct required by pol it eues qe is defined by the three "Hyponyme" sthkete, sunaqlounte and mh; pturomenoi (Schenk 1984:166). A conduct worthy of the gospel thus means to stand firm, to be united in a common struggle for the gospel and against the opponents. The struggle is not only against the opponents, but first and foremost for the truth of the gospel: "Paul is interested not only in fending off the attacks, but also and mainly is spreading God's glorious, redemptive truth which centers in Jesus Christ and salvation in him" (Hendriksen 1961:87. So also O'Brien 1991:154 and Fee 1995:163).

This proclamation of the gospel - so Paul continues - is a sign to the opponents of their destruction, but of the Philippians' salvation, "and this from God" (kai; t out o apo; qeou', 1:28). According to Vincent (1961:35) tout 0 refers to the whole preceeding statement: the enemies' destruction, the salvation of the Philippians and their perseverance. Everything they experience in their attempts to proclaim the gospel is from God.

This is a clear example of an argument based on divine involvement. God is carrying out his plan and their experiences are all part of that divine programme. He, who began a good work in them, will carry it on toward completion (1:6). The function of this 
brief statement is to persuade the Philippians to persevere in proclaiming the gospel, since God is the primary agent in the advancement thereof.

In 1:29-30 Paul explains the statement in 1:28, and especially the emphatic kai; t out o a p o; qeou' at the end. Literally: "For to you it has been granted (o $i$ umin ejarisgh) on behalf of Christ not only to believe in him, but also to suffer on his behalf, having the same conflict (t on aut on ag wha ef ont e ) which you saw in me, and now hear about me".

The following two issues are of rhetorical significance:

Firstly, the passive efarisgh that continues the argument in 1:28: God is the one that has given them the privilege of believing in and suffering on behalf of Christ. The Philippians should view their suffering in a positive light for two reasons: because God is involved; and because they are suffering on account of, out of devotion for, Christ. Suffering on account of Christ in this context, means suffering for the advancement of the gospel. And God has given them that privilege.

Also rhetorically significant is the concluding statement in 1:30: "having the same conflict that you saw in me, and now hear about me". The reference here is to Paul's experience during his first visit to Philippi (when he was shamefully treated, Acts 16:16-24) and to his current imprisonment in Rome (where he is experiencing conflict and affliction, 1:12-26). The Philippians' conflict is the same ( $t$ on a uf on). They have been persecuted for the same reason (the advancement of the gospel) and by the same adversaries (the opponents from outside). The focus is on "the same", as Loh and Nida (1977:44) and Fee (1995:172) have pointed out, and not on Paul as an example to be followed, as Silva (1988:98) argues. Supporting this interpretation is the placement of t on a uf on a g wha ef ont $e \sim$ at the beginning of 1:30.

The argument used here is an argument based on shared experience. They are in it together. The sufferings of both Paul and the Philippians were the direct result of their involvement in proclaiming the gospel, and they both stood firm in their struggle against the opponents. By using this indisputable argument, Paul is affirming the common gound between himself and the Philippians, which is a very effective rhetorical strategy. It not only strengthens the relationship between them, but it also serves to persuade his 
audience to persevere in their common cause: the progress of the gospel in a world that is openly hostile to that cause.

Some rhetorical techniques have already been highlighted: the chiastic pattern in 1:27, the emphatic position of kai; t out 0 ap 0 ; qeou ' (at the end of 1:28) and of t on a ut on a g wha (at the beginning of 1:30). The following two techniques are also used to enhance the communication in this phase (1:27-30):

The parenthesis in 1:27: eif e el qwn kai; ijwn uma $\sim$ elte apwn. According to Tolmie $(2005: 80)$ a parenthesis is "a technique used to alert the audience to the content of a statement". In 1:27 it is used to make clear that Paul's absence did not justify a relaxing of their perseverance; they should persevere regardless of his presence or absence.

The metaphors sthkete and sunaql ount e in 1:27, as well as a g wha in 1:30 are all taken from war and used to signify the struggle of the Philippians in a graphic way.

To summarise: Paul's rhetorical strategy in 1:27-30 can be described as "exhorting the Philippians to persevere in proclaiming the gospel". Such exhortations are based on the assumption that a close relationship exists between Paul and his audience - a relationship that both parties want to maintain. He begins his argument by stating the one thing (momon) that concerns him: the lack of steadfastness and unity in the face of external pressures. The importance of perseverance is highlighted by, amongst others, the verbs s thket $e$ and suna ql ount $e \sim$, arranged in a chiastic pattern to emphasize the fact that the struggle of the Christian citizen takes place within the believing community and requires uninamity.

The struggle is for the advancement of the gospel ( $\mathrm{h} / \mathrm{p}$ i g t ei tou'eujggeliou, 1:27). In order to persuade the Philippians to persevere in their task, Paul uses an argument based on divine involvement: everything they experience in their attempts to proclaim the gospel, is from God (1:28).

In 1:29-30 Paul continues the argument of divine involvement by using the passive efarisgh: God is the one who has granted them the privilege of believing in and suffering on behalf of Christ (1:29). There are two reasons why the Philippians should view their suffering in a positive light: because God is involved, and because 
their suffering is on account of Christ, which means (in this context) suffering for the advancement of the gospel.

In his concluding statement Paul uses an argument based on shared experience $(1: 30)$. The function of the argument is to strenghten the relationship between himself and the Philippians, and to persuade them to persevere in their common struggle: they are not alone in the struggle for the progress of the gospel. They are in it together.

Rhetorical techniques identified in this phase are the parenthesis in 1:27, the emphatic placement of words at the end (1:28) and the beginning (1:30) of sentences or clauses and the use of metaphors from war (1:27 and 30).

\subsection{Philippians 2:1-11. Exhorting the Philippians to live the Gospel}

In this phase Paul continues his exhortations, but with a difference: his focus shifts from the Philippians' outward struggle to their internal problems. His aim is to persuade the Philippians to live a life devoid of dissension and self-centeredness. They are to live in unity and humility and to persuade them to do so, he uses strong arguments and some striking rhetorical techniques.

This phase is well-known due to the attention paid to the Christian hymn in 2:6-11. Before commencing with a detailed analysis of the phase, it is necessary to make some remarks on 2:611:

The background of the hymn is hotly debated (see, for example, Schenk 1984:190-209; Silva 1988:104-106; O'Brien 1991:263-271 and Fee 1995:192-194). The hymn may be prePauline, as is generally accepted, but the over-emphasis on its original setting isolates it from the immediate context in which it has been transmitted. This does not mean that the question of its origin is not important for proper exegesis. The reconstruction of its background surely provides one of the contexts against which the hymn must be interpreted. For the purpose of this article, however, it is not that important.

The coherence of 1:27-2:18 from a rhetorical perspective has already been addressed. The way in which the hymn functions in this context, is our main concern. The question is: How does this passage 
contribute to Paul's objective of persuading the Philippians to live a life worthy of the gospel?

In order to answer this question, the hymn will be regarded as a unit that need not be analyzed in detail. The style of the passage - its rhythms, wel-balanced clauses, antitheses and parallelisms - has been described in many publications (cf Snyman 1989:47-49. For bibliographies see, amongst others, Martin 1983 and Müller 1993:89). However, such analyses are not part of a study aimed at determining the rhetorical function of the hymn. The same applies to the origin and meaning of uncommon words and ideas not found in other letters of Paul (For a discussion of these, see the doctoral dissertation of Pelser 1971).

Assuming that the hymn has a pre-Pauline origin, it is important to know whether Paul deviated from its original composition or not. Any deviation would be rhetorically important. Scholars are in agreement that the clause qa na tou de; st a ur ou '" "the death of the cross", 2:8) has been added by Paul. Its function will be discussed below.

Phil 2:1-11 begins with four eif-clauses, which could be interpreted as either conditional ("if") or causal ("since"). Literally:

"Therefore, if there is any / since you have experienced (ei $[\mathrm{t} i \sim$ ) exhortation in Christ;

if there is any / since you have experienced (ei $[\mathrm{t} i$ ) encouragement of love;

if there is any / since you have experienced (ei[t $i \sim)$ fellowship of the Spirit;

if there is any / since you have (ei[ $\mathrm{ti} \sim)$ kindness and compassion,

make my joy complete ( $\mathrm{p} / \mathrm{hr}$ ws at evmou thn caran) by being of the same mind (ija t 0 ; a ut o; f r onht e), having the same love (thn auf hn agaphn ef ont e ), with souls united (s umy ucoi), setting your minds on unity (t 0 ; eh f r onount e $)$ " (2:1-2).

The choice between a conditional or causal interpretation of the "if"clauses is rhetorically important. Silva (1988:102-103) prefers a conditional interpretation and warns against "the tendency to translate with 'since' (cf Schenk), for this rendering weakens the rhetorical force of the passage" (1988:103). He is of the opinion that 
the four clauses are deliberately vague, because the appeal in 2:2 is very emotional: the clauses are "not intended to function as a set of four rational, theological arguments but rather as impassionate pleading" (1988:102). However, the majority of commentators (Schenk 1984:173-4; Loh and Nida 1977:47; O'Brien 1991:165, etc.), as well as recent translations (TEV, NEB and the 1983 Afrikaans translation) prefer a causal interpretation of the passage, in which the personal experiences of the Philippians form the basis of the exhortation in 2:2. Out of these experiences grows, logically, the exhortation to make the apostle's joy complete.

Which interpretation is to be preferred? In my opinion, the causal interpretation is the correct one for the following reasons:

The "if"-clauses are structured in such a way that they logically accumulate in the exhortation of 2:2. Such structures imply rational argumentation, which is an important feature of the phase (2:1-11), as well as the section (1:27-2:18), under discussion.

The personal character of a causal interpretation is in line with the apostle's approach in other parts of the letter $(1: 3-4,8,12,24-25$; $2: 12,17-18,24 ; 3: 1 ; 4: 15)$.

Thus, Paul bases his exhortation in 2:2 on definite realities in the experience of the Philippians, intended to have a much larger impact than a list of impersonal conditions. If this interpretation is correct, it is an example of an argument based on own experiece. Paul's main aim in 2:1 is to ground his exhortation for unity in the realities of the Philippians' own experiences: encouragement in Christ, their love, fellowship of the Spirit, and tenderness and compassion. Arguments based on own experiences are effective, because they are selfevident and cannot be denied. By using this type of argument here, Paul is trying to persuade the Philippians to add to their list of spiritual experiences the crucial one of unity through humility, thereby making his joy complete.

The verb $\mathrm{p}$ I hrow means "to cause something to become full "to fill"' (Louw and Nida 1988:598). pl hrws at e presupposes that the Philippians are already a source of joy to the apostle. It also supports the interpretation of eij in 2:1 as causal: "Von diesem speziellen Gehalt des imperativischen Nachsatzes her (i. e. that plhrws ate represents a climax - 'Steigerung' - in 2:1-2) ist die Entscheidung zu fallen, dass das betonte vierfache eij von V.1 darum betont ist, weil es jeweils einen wirklichen Fall voraussetzt, also 
nicht mit 'wenn', sondern mit 'da' übersetzt werden muss" (Schenk 1984:173). Implicit in p/hrwsate is, therefore, a reference to the Philippians' spiritual experiences, which are (as realities) a source of joy to the apostle. The clause $p / h r$ ws at evmou thn caran exhorts the Philippians to continue living the gospel, as they have done up to now.

However, Paul's joy is incomplete due to internal dissensions in the Philippian church. The need for uninamity is emphasized by several expressions, which are relevant to it: t 0 ; a ut 0 ; ( $f$ ronht e), thn authn (agapha), sum-(yucoi) and to; eh (f ronounte 2 ). (O'Brien 1991:65). Unity of mind is Paul's main concern in the exhortations of 2:1-4. Silva (1988:100) agrees with Hawthorne that this concern, expressed in the four subordinate clauses that follow the main verb plhrwsate, is the primary thought of the whole passage, and not Paul's exhortation for complete joy. This concern for unity proves that the construction of the rhetorical situation (2 above) is correct: the letter is a response to the internal unrest and dissension in the Philippian church, and not just a letter of friendship aimed at maintaining the relationship between Paul and his audience.

The key to unity is humility. Paul stresses the importance of humility by using the technique of antithetic presentation in 2:3-4: Literally: "Do nothing from selfish ambition or from empty conceit (mhden katjejiqeian mhde; kata; kenodoxian), but in humblemindedness each counting the other better than himself $(a|| a ; t h \mid$ tapeinof rosumh/ al I hvou hgoumenoi uperecont a eaut wn; each looking not only to his own interests ( $m$; $t$ a; ela ut wh ekas t 0 skopount e ), but also to the interests of others (a)la; [kai, ta; ef erwn elkast oi "). No verb is used in the first exhortation (2:3). In this way the sense is brought out more forcefully (Loh and Nida 1977:51). The noun t a peinof ros unh, which is the main concern of this exhortation, is defined contextually by its opposition to the nouns ej iqei (which already appeared in 1:17 and used to describe those who preach the gospel with impure motives) and the hapax kenodoxia (which Louw and Nida 1988:765 define as "a state of pride which is without basis or justification - 'empty pride, cheap pride, vain pride"'). The antithetic presentation not only explains the meaning of tapeinof rosumh, but it also increases the force of the statement. Antithetic presentation focuses attention on the "but"-part of the statement (Tolmie 2005:42 and 58) - here to count the other better than oneself. 
The true obstacle to unity is self-centeredness (2:4). Paul once more uses the technique of antithetic presentation to address this issue: "And look out for one another's interests, not just for your own" (TEV). Its function is the same as in $2: 3$, namely to add force to the statement.

Finally, Paul exhorts his audience with the words: "The attitude you should have is the one that Christ Jesus had", 2:5, TEV). The question whether the hymn that follows commends imitation of Christ's self-denial or his humility is not that difficult to answer. Both interpretations are valid, as represented by ekerws en (2:7) and ef apeinws en (2:8) respectively. These two verbs embody the central thought of the hymn and serve to illuminate each other.

Two issues regarding the hymn are important for a rhetorical analysis of the letter:

The first relates to its internal structure. Lohmeyer (1961:5-6), Martin (1983:133), Silva (1988:106) and others divide the hymn into six three-line stanzas. The first three (2:6-8) deal with Jesus's humiliation and the last three (2:9-11) with his exaltation. The arrangement is not without difficulties, but scholars find it exegetically useful. From their thorough analyses of the stanzas, it is clear that the words qanatrou de; st aurou'at the end of 2:8 create the biggest problem for a strophic arrangement of the hymn. It breaks the poetic pattern and is probably inserted by Paul to impart his own distinctiveness to the passage (Silva 1988:122-3).

If this is correct, the phrase is rhetorically significant. By means of the technique of correctio (met abol hy Paul stresses the fact that the death of Jesus was not a natural one, but the accursed death of the cross. In ancient rhetoric this technique was used to highlight the correction, thereby impressing it upon the audience (Anderson 2000:71). Death on a cross was considered the most degrading death possible. The addition of qa na trou de; $s$ t a ur ou 'thus serves to emphasize the depth of Christ's humiliation and obedience.

Because of his self-humiliation Christ was exalted by God (2:9-11). It is a vindication of all that his suffering involved (Martin 1983:232). For his very reason (div) God raised him to the highest place and gave him a name that is greater than any other name (2:9). All will acknowledge that He is Lord, to the glory of God the Father (2:10-11). 
Secondly: Could the hymn be regarded as an example? Some theologians have argued that Christ's humiliation and exaltation were such unique, redemptive acts that they could not be used as an example. The majority of exegetes, however, agree that this viewpoint does not necessarily exclude an ethical interpretation of the hymn (For a discussion, see Silva 1988:107-111). The conclusion of the debate is aptly summarised by Hendriksen (1971:103): "To be sure, there is an area in which Christ cannot be our example. We cannot copy his redemptive acts. We cannot suffer and die vicariously... But with the help of God we can and should copy the spirit that was basic to these acts. The attitude of self-renunciation with a view to helping others should be present and should grow in the life of each disciple. And that is the point here (see verses1-4)". He supports his summary by referring to other passages where Jesus is depicted as our example: Matthew 11:29; John 13:12-17, 34; 21:19; 1 Corinthians 11:1, 1 Tessalonians 1:6, etc.

Philippians 2:6-11 could thus be regarded as an argument based on example. This kind of argument is effective, because it is relatively easy to understand. Once the audience grasps the example, they can apply it to the issue under discussion, in this case (2:1-4) Paul's exhortation to unity and humility. He uses this argument to reinforce instruction to Christian living. His aim is to persuade the Philippians to live a life devoid of internal unrest and dissension. Such a life has as its basis an attitude of humility. Internal unrest was the main issue that plagued the church in Philippi and accasioned the letter. And what better example could he use than the example of the One to whom they are all united in faith?

A natural consequence of humiliation is exaltation. As the Philippians follow Christ in his humiliation and obedience, so will they follow him in his exaltation. There is a reward for those who persevere in living the gospel: the eschatological vindication that awaits all who follow Christ's example. The prospect of this vindication is meant to persuade the Philippians to persevere in living lifes of humility, an attitude that is the key to the much needed unity in the church in Philippi.

In addition to the rhetorical techniques of antithetic presentation (2:3-4) and correctio (2:8), the following also deserves attention: 
$>\quad$ The repetition of eijt $\mathrm{i} \sim$, followed by four brief statements in $2: 1$, are forceful and serve to emphasize the earnestness of Paul's argumentation, which is the result of the reports of internal unrest in the church in Philippi (Vincent 1961:53).

$>\quad$ In 2:2 there is a repetition of synonymous phrases to ensure that the Philippians do not miss the point:

"that you set your minds on the same thing

having the same love

together in soul having your minds set on the one thing".

(Fee 1995:182-3).

This technique proves that unity of mind is Paul's main concern in $2: 1$, and not his exhortation to complete joy. sounds):

In $2: 4$ there is an example of alliteration (the repetition of
A éaut wǹ elkas to
B et erwǹ ekas toi

Nida et. al. (1983:24) remark that "similarity of sound may ...involve similar or contrastive meanings". Here the assonance is "an intentional repetition of sound", aimed at contrasting the roleplayers in an effective way.

To summarise: The rhetorical strategy in 2:1-11 can be described as "exhorting the Philippians to persevere in living the gospel". Paul begins this phase with four "if"-phrases, which are to be interpreted as causal and personal, not conditional. As such they could be regarded as an argument based on own experience. Since these spiritual experiences are self-evident and cannot be denied, they are effective in persuading the Philippians to live a life of unity, thereby making Paul's joy complete.

The verb plhrwsate $(2: 2)$ presupposes that the Philippians are already a source of joy to Paul and exhorts them to continue living the gospel, as they have done up to now. However, Paul's main concern in 2:2 is not his own joy, but the need for unity, as emphasized by the four subordinate clauses that follow pl hrws a t e thn caran. This emphasis is a response to the internal unrest in the Philippian church. 
The key to unity is humility. Paul emphasizes this fact by using two forceful techniques in the exhortation of $2: 3$. The first is the omission of a verb in the first part of the sentence. The second is the antithetic presentation mhden... mhde; alla;., which focuses attention on the last part of the sentence dealing with humility. Antithetic presentation is also used in the exhortation of $2: 4$, with the same function.

Scholars are in agreement that the clause qanatou de; st a urou' in 2:8 was added by Paul, since it breaks the strophic arrangement of the hymn. The technique is known as correctio and serves to highlight the depth of Christ's humiliation and obedience. The hymn itself could be regarded as an argument based on example. It serves to persuade the Philippians to:

live a life of humility and obedience, as Christ himself did, and persevere in living the gospel, because it will end in vindication and exaltation.

Other rhetorical techniques used in 2:1-11 are the repetition of eij $\mathrm{t} i \sim$ and the four brief statements in 2:1, the repetition of synonymous phrases in 2:2 and assonance in 2:4.

\subsection{PHILIPPIANS 2:12-13. EXHORTING THE PHILIP- PIANS TO PERSEVERE IN LIVING THE GOSPEL}

The connection between this phase and the previous one is established by the introductory w\$t e, a g a pht oi vmou: Literally: "So then, my beloved, as you have always obeyed (uphkous ate), not only in my presence, but now much more in my absence, work out your own salvation (thn elaut wh s wthrian katergages ge) with fear and trembling, for it is God who works in you (qeo; $r$ a v es $t$ in ol ejergwn en uminh), to will and to work (kai; t o; qevein kai; t o; ejergein) for his good pleasure".

The verb uphkousate ("obey") refers back to $2: 8$, where Christ's supreme humility and obedience were described: "He was humble and walked the path of obedience all the way to his death on the cross" (TEV). Philippians 2:8 connects the Christian hymn to its surrounding context. The concept of humility refers to the preceeding context $(2: 1-4)$, and that of obedience to what follows in $2: 12-13$. Obedience is the only concept picked up and strongly linked to the hymn by the conjunction w\$te. Furthermore: the qualification of Christ's obedience in 2:8 as an obedience unto death, 
"the death on the cross", was added by Paul and is as such rhetorically significant. The hymn is therefore as much an example of humiliation/exaltation, as of obedience. As an argument from example, it has the same function here as in the previous phase (3.3 above).

The content of 2:12-13 is similar to 1:6-7 and deals with human and divine activity in the salvation of the Philippians. At stake is the Philippians' own salvation, as evidenced by their continued obedience. Phil 2:12 is thus what Schenk (1984:167) would call "gemeindliche Verkündigung". It is meant to address the internal unrest in the Philippian church by exhorting them to be obedient, as Christ has set the example. The One involved with this process is - as in 1:6 - God himself (2:13).

The following issues are of rhetorical impotance:

Firstly, the meaning and function of thn efut wh s wthrian kat ergages qe ("work out your own salvation"). As to swthrian, the question is whether it refers to the individual believer or the life of the community. After discussing the two possibilities, Silva (1988:138) concludes that the one does not exclude the other: "In the particular context of Philippians 2, the outworkings of the believer's personal salvation take the form of corporate obligations within the Christian community: the duty of seeking the good of others".

The meaning of katergazesqe is "to do something with success and /or thoroughness - 'to accomplish, to perform successfully, to do thoroughly" (Louw and Nida 1988:512). Its meaning in this context is determined by, inter alia, the chiastic pattern in 2:12:

A As you have always obeyed

B not only in my presence

B but now much more in my absence

A work out your own salvation...

To work out one's own salvation could thus be regarded as one way of being obedient (Silva 1988:135 and Fee 1995:234-5). The spirit of obedience is to be manifested continuously in the life of the church in Philippi.

Secondly, in the same way as they have always been obedient (kaqw; pant ot e uphkousate), the Philippians should continue to 
work out their own salvation. The word ka qwi probably refers to the positive way in which the Philippians responded when they first heard the gospel (Acts 16:14, 32-33). However, pa nt ot e ("always") suggests something more than their initial response; it suggests that the behaviour of the Philippians has consistently been characterised by obedience, in line with the example of their Lord.

This is an argument based on past achievement. This type of argument is effective, because it provides concrete evidence that they were able to obey in the past, and will thus be able to do so in future. By using this argument here, Paul is trying to persuade the Philippians to persevere in living the gospel by continuing their behaviour up to now.

Thirdly, the parenthesis "not as in my presence only, but much more in my absence" has been interpreted in various ways. The question is whether it should be connected with the previous statement "as you always obeyed me", or with the exhortation "work out your own salvation". Schenk (1984p:214-5) connects it to the preceeding statement, because it expands on p a nt ot e. He translates: "weil ihr standig eure Auftragstreue bewiesen habt, und weil ihr das nicht bloss in meiner Anwesenheit, sondern jetzt noch viel starker wahrend meiner Abwesenheit getan habt, so setzt eure Arbeit...fort" (Schenk 1984:226). Fee (1995:231), as well as the TEV and 1983 Afrikaans translation also link it to the preceeding statement.

However, the majority of commentators (Vincent 1961:64; Müller 1976:90; Silva 1988:134,140-1; Müller 1993:115 and O'Brien 1993:276) connect the parenthesis with "work out your own salvation", mainly because the negative mhv is used with the imperative katergazes qe and not ouj(which would have been the case if connected with the preceeding indicative uphkous a t e).

Which interpretation is to be preferred? In my opinion, 2:12 (though a complicated sentence) does not create a serious interpretation problem, due to the following reasons:

*Obedience is one way of working out one's salvation, as supported by the chiasm. Since the meaning of the preceeding uphkous a te and the following kat ergazes ge is the same or nearly the same, the parenthesis could be connected with either one of the two without effecting the trend of the argument that much. 
* Most importantly, the rhetorical function of the parenthesis is the same as in 1:27: the Philippians should continue to live the gospel, regardless of Paul's presence or absence. Especially his absence (pollw/mallon ej th/apousia/mou) does not justify a relaxing of their obligations; they should be consistent in their obedience or the working out of their salvation. "Perseverance does not admit of interruptions" (Silva 1988:91).

Fourthly: Underlying the phrase a l a nunh...apousia/mou is the close relationship between Paul and the Philippians. This relationship was so strong that he could assume they would do what he asks, whether he is with them or not. He relies on the fact that the Philippians would act in a way consistent with this relationship - not only in his presence, but especially now in his absence. Especially now, Paul is convinced that they would try their best not to disappoint him.

*Finally, the gav in 2:13 provides the reason for the entire phrase met a; f obou ...katergayes qe and states that it is God who works in them both to will and to work for his good pleasure. The Philippians should work out their own salvation "with fear and trembling", because it is God's good pleasure that they should do so. To that end, He extends his influence not only to their activity, but also to their very will (Vincent 1961:66-7). This is another example of an argument based on God's involvement. The Philippians are dependant on God to work out their own salvation. And that involvement is a comprehensive one. Since God is working in them to will and to work out their own salvation, the Philippians are indeed able to do so. By using this powerful argument here, Paul is once more trying to persuade the Philippians to persevere in living the gospel, thereby addressing the unrest in their midst.

Paul enhances his communication in $2: 12-13$ by using the following rhetorical techniques:

The direct address agaphtoiy strengthened by the personal pronoun mou, shows the apostle's deep affection toward the Philippians.

The imperative kat ergages qe is emphasized by its position at the end of $2: 12$.

The periphrastic construction in 2:13 (qeo; gav estin 0 l ejergwn en umi h̀: "God is the one who works in you") emphasizes 
the Philippians' dependence on God for working out their own salvation. God (at the beginning of the sentence) is the primary agent: because He works, the Philippians can persevere in living the gospel.

Schenk (1984:218-9) draws attention to the chiastic arrangement of the subjects in 2:13:
A olejergwǹ
B to; qevein
(God)
B to;ejergein
(Men)
A uper thi eujlokia (God)

The reference to God at the beginning and the end of the chiasm serves to highlight Him as the one who works for his good pleasure.

The two substantive infinitives (kai; to; qevein kai; to; ejergein), rather than nouns, emphasize the energy involved, while the two ka is indicate that both - the willing and the working - are of God (Vincent 1961:66).

To summarise: The rhetorical strategy in 2:12-13 can be described as "exhorting the Philippians to persevere in living the gospel". The conjunction w\$ t e links the exhortation closely to the preceeding hymn - especially to $2: 8$, where it was stated that Christ was obedient unto death, "the death of the cross". The fact that Paul most probably added these words to the original hymn, and the fact that "obedience" is the only concept elaborated on in 2:12-13, make the hymn as much an example of Christ's humiliation as of his obedience. Thus the hymn is an argument from example for what precedes in 2:1-4, as well as for what follows in 2:12-13.

The meaning of katergazesqe is determined by, inter alia, the chiasm in 2:12: to work out their own salvation is one way of being obedient. The phrase kaqwi pant ot e uphkousate suggests that the Philippians have consistently been obedient, in line with the example of their Lord. This is an argument based on past achievement and used to persuade the Philippians to persevere in living the gospel: since they have already proved their ability to obey, they will be able to do so in future.

The parenthesis "not only in my presence, but much more now in my absence", could be connected with both uphkousate and kat ergazes qe without effecting the trend of the argument. It serves to emphasize the need for consistency and perseverence, regardless 
of the Philippians' circumstances. The fact that Paul could assume that they will heed to his request especially in his absence, once more proves his close relationship with the Philippians.

Philippians 2:13 is an argument based on divine involvement. The Philippians will be able to work out their own salvation, because God himself will enable them to do so. With this assurance Paul once more tries to persuade the Philippians to persevere in living the gospel.

Rhetorical techniques used in these two verses are direct address, parenthesis, the placement of words at the beginning and end of sentences/phrases, chiasms and the use of substantive infinitives rather than nouns to emphasize activity.

\subsection{PHILIPPIANS 2:14-18. EXHORTING THE PHILIP- PIANS TO PERSEVERE IN PROCLAIMING THE GOSPEL}

Paul finally returns to the proclamation of the gospel when he exhorts the Philippians to do "everything without complaining and arguing, so that you may be innocent (amemptoi) and pure (akevaioi), God's perfect children (tekna qeou'a nnwma) in the midst of a crooked and perverse generation, among whom you are shining as stars in the universe, holding forth the word of life (l og on zwh $\sim$ eperont e $)$ " (2:14-16).

Only by doing everything "without complaining and arguing" will the Philippians be able to fulfill their mission in the world. This prepositional phrase, that qualifies the exhortation, is rhetorically significant. Silva (1988:143-5) argues that the reference here might well be to the murmuring of the Israelites in the wilderness (Exod $15: 24 ; 16: 2,7-9,12$, etc). He finds a parallel in 1 Corinthians 10:113, where Paul also uses the experience of the Israelites in the wilderness to motivate proper Christian behaviour. And the Corinthian church was also plagued by dissension. The murmuring of the Israelites was directed against God, but in the person of his representative Moses. From this Silva draws two conclusions. Firstly, that the divisions in the Philippian church are related to complaints against their leaders. And secondly, that Paul's allusion to the experience of the Israelites in the wilderness should alert the Philippians to the possibility that their own divisions could be interpreted as quarreling against God. Supporting this interpretation of protest against church leaders in Philippi, is Paul's request in 2:29: "Show respect to all such people as he (Epaphrodites), because 
he risked his life...ffor the sake of the work of Christ...". If correct, the phrase "without complaining and arguing" provides an important clue as to the nature of the unrest in Philippi.

The passage 2:14-16 deals with what Schenk (1984:167, 2234) would call "Evangeliumsverkündigung" and illustrates how closely related it is to "gemeindliche Verkündigung". The Philippians are performing their missionary work by holding forth (eperont e ) the word of life, that is, the gospel of salvation, to a corrupt and perverse world. (Loh and Nida 1977:71. For an alternative interpretation and motivation of ejec ont $e \sim$ as "to hold fast”, see O'Brien 1993:297. Hendriksen (1961:125-6) has already discussed these two possibilities and concluded - correctly - that "to hold forth" suits the context best).

Their missionary work, so Paul continues, will give him reason "to be proud of you on the Day of Christ (eij hmevan Cristou), because it will show that I did not run in vain or labour in vain (ouk eij kenon edramon ouje; eij kenon ekopiasa)" (2:16). In 1:6 (and 10) Paul already referred to "the Day of Christ". In that context its function was to persuade the Philippians to persevere in proclaiming (and living) the gospel. It might have the same function here: if the Philippians will persevere to conduct themselves in this way, then - on that Day and as a reward - Paul will be able to point with pride to their missionary work. It will prove that he did not run or labour in vain - something that the Philippians would try to avoid at all cost, due to the close relationship between themselves and the apostle.

In 2:17 and 18 Paul summarises his argument. If the Philippians will continue to work out their own salvation (=live the gospel), and if they will continue to hold forth the word of life (=proclaim the gospel), then there will be reason for joy - even if he himself is to be poured out as a libation in addition to (epiy the sacrifice and service of their faith (2:17) (Vincent 1961:71). Even then there will be reason to rejoice, for his death will be to the honour of God and the welfare of the church. Therefore he exhorts the Philippians to rejoice and to be glad with him, who brought them the word of life (Müller 1976:96).

Two issues are rhetorically significant in these concluding verses: 
*Firstly, the phrase in 1:17:a : "But even if I am to be poured out as a libation in addition to (ep i i the sacrifice and service of your faith (th/qusia/kai; l eit ourgia/th 〜 pistew umwñ)". Vincent (1961:71-2) argues convincingly that ep i vmeans "in addition to" and not "upon" (see also Müller 1976:96). But the meaning of the genitive construction is still debated, as is reflected in various translations. The $N E B$, for example, translates: "that sacrifice which is the offering up of your faith". This rendering regards "faith" as the thing offered, thus as an objective genitive. The $T E V$, on the other hand, interprets the construction as a subjective genitive in the sense of "your faith offers a sacrifice". Here the Philippians' faith is the source of their offering. According to Loh and Nida (1977:74-75), Schenk (1984:225) and Silva (1988:151) the context (1:5, 1:7, 2:30 and especially $4: 18)$ justifies this second interpretation.

If correct, it is another example of an argument based on past achievement. Paul is here referring to the Philippians' life and conduct of the past as offerings that sprang from their faith. This point is rhetorically significant, because it affirms the genuineness of their commitment: the gift that Paul has received through Epaphroditus, their participation in the gospel, their conduct up to now - all these sacrifices have their origin in the faith of the Philippians. This argument is effective, because Paul is not only recognizing their worth and participation in the gospel up to now (something they are well aware of), but he is also describing their contributions in the best light possible: they have their origin in the faith of the Philippians. By using this argument, Paul is trying to persuade his audience - who had lost their sense of Christian joy - to rejoice again.

*Secondly, $2: 17 \mathrm{~b}-18$ affirms the special relationship between Paul and the Philippians. Their faith and ministry of the past are already grounds for rejoicing. But even if Paul's life should be poured out as an additional libation, there is cause for joy, because Christ will be magnified (1:20). Both Paul and the Philippians had reason for joy, because their faith offers sacrifices that demonstrate their complete devotion to the cause of the gospel. For the same reason (t 0 ; de; a uf ov 2:18) he exhorts them to rejoice and to be glad with him. Just as they have shared the same struggle (1:30), so they should share the same joy. The exhortation in $2: 17 \mathrm{~b}-18$ thus serves to affirm (and strengthen) the relationship between them. 
The following rhetorical techniques have been identified in 2:14-18:

- The terms a memp toi, akevaioi and a mwma in 2:15 are used for stylistic reinforcement, emphasizing the blameless conduct required of the Philippians.

- $\quad$ The lack of a connecting particle in 2:14 (asyndeton) links pant a poieit e closely to the preceding verse: "do" picks up on the verb "obey" (which means "to work out your salvation"), while "all things" have to do with everything that characterizes their corporate life in Philippi (Fee 1995:243).

- The repetition ouk eij kenon edramon oujle; eij kenon ekopiasa (2:16) emphasizes "in vain" as the dominant thought (Vincent 1961:70), while both verses are metaphors from an athletic contest.

- The pleonasm umei $\sim$ c a ivet e in 2:18 is used to strenghten the final exhortation to rejoice (Schenk 1984:226).

To summarise: Paul's rhetorical strategy in 2:14-18 can be described as "exhorting the Philippians to persevere in proclaiming the gospel". Fperont $e \sim$ in 2:16 is to be interpreted as "holding forth" and refers to their missionary work, while "the day of Christ" is used to persuade the Philippians to persevere in proclaiming the gospel. In doing so, Paul would not have run or labour in vain, something the Philippians would try to avoid at all cost, due to their close relationship with the apostle.

The genitive construction th/ qusia/..th $\sim$ pistew umwn (2:17) is a subjective genitive, meaning "your faith offers a sacrifice". It is used to affirm the genuineness of the Philippians' commitment by describing their contributions in the best light possible: the contributions have their origin in the faith of the Philippians. This argument from past achievement is used to persuade the Philippians to rejoice again. The concluding exhortation to rejoice with him $(2: 18)$ is another indication of the close relationship between the Philippians and Paul: just as they have shared the same struggle (1:30), so they should share the same joy.

Rhetorical techniques used in 2:14-18 are the asyndeton in $2: 14$, stylistic reinforcement in 2:15, the repetition of eif kenom and 
the use of metaphors from an athletic contest in 2:16, and the pleonasm in 2:18.

\section{CONCLUSION}

The aim of this article was to prove that it is not necessary to use rhetorical models from outside to understand Paul's persuasive strategy in Philippians, provided that one reads the text carefully and systematically.

Philippians 1:27 - 2:18 is demarcated as a section for analysis due to the exhortations in $1: 27,2: 2-5,2: 12,2: 14$ and $2: 18$. The dominant rhetorical strategy could be described as "exhorting the Philippians to persevere in living and proclaiming the gospel". The section was divided into four phases, based on the unfolding of Paul's argument: 1:27-30 (exhorting the Philippians to persevere in proclaiming the gospel); $2: 1-11$ (exhorting them to persevere in living the gospel); $2: 12-13$ (exhorting them to persevere in living the gospel) and 2:14-18 (exhorting them to persevere in proclaiming the gospel).

The dominant rhetorical strategy in this section is in response to a situation where the Philippians were experiencing great adversity, internal unrest and a lack of Christian joy. In order to persuade them to persevere, Paul uses various rhetorical strategies and techniques. In analyzing these, the focus was on exegetical issues that could have a rhetorical impact, on the types of arguments used, on the way Paul argues and on the rhetorical techniques that could enhance the impact of the communication. Examples of arguments based on divine involvement, on own and shared experience, on example and on past achievement have been identified, while the emphatic position of terms, parenthesis, the repetition of terms, striking metaphors, chiasms, brief statements, asyndeton, direct address, pleonasm, antithetic presentation, correctio, the use of a periphrastic construction and of substantive infinitives rather than nouns all contribute to the impact of Paul's argumentation and serve to persuade the Philippians to persevere in living and proclaiming the gospel.

\section{Consulted literature}

Anderson R D 1999. Ancient Rhetorical Theory and Paul. CBET 18. Leuven: Peeters. 
Anderson R D 2000. Glossary of Greek Rhetorical Terms Connected to Methods of Argumentation, Figures and Tropes from Anaximenes to Quintilian. CBET 24. Leuven: Peeters.

Betz H D 1979. Galatians. A commentary of Paul's Letter to the churches in Galatia. Philadelphia: Fortress.

Brown R E 1997. An Introduction to the New Testament: Letter to the Philippians. The Anchor Bible Reference Library. New York, London, Toronto, Sydney, Auckland: Doubleday.

Fee G P 1995. Paul's Letter to the Philippians. The New International Commentary on the New Testament. Michigan, Grand Rapids: WB Eerdmans.

Hendriksen W 1962. Phillppians. New Testament Commentary. Grand Rapids: Baker.

Kern P H 1998. Rhetoric and Galatians. Assessing an Approach to Paul's Epistle. SNTS. MS101. Cambridge: Cambridge University Press.

Loh I J \& Nida E A 1977. A Translators Handbook on Pauls' Letter to the Philippians. Helps for Translators. Vol 19. Stuttgart: United Bible Societies.

Lohmeyer E 1974. Der Brief an die Philipper. Göttingen: Vandenhoeck \& Ruprecht.

Louw J P \& Nida E A 1988. Greek-English Lexicon of the New Testament Based on Semantic Domains. New York: United Bible Societies.

Marshall P 1987. Enmity in Corinth. Tübingen: WUNT 2/23.

Martin R P 1983. New Testament hymns: Background and development. ET 94, 132-136.

Matter H M 1965. De Brief van Paulus aan de Philippenzen en de Brief aan. Philemon. Commentaar op het Nieuwe Testament. Kampen: Kok.

Müller J J 1976. The Epistles of Paul to the Philippians and Philemon. The New International Commentary on the New Testament. Michigan, Grand Rapids: WB Eerdmans.

Müller U B 1993. Der Brief Des Paulus an die Philipper. Theologischer Handkommentar zum Neuen Testament. Leipzig: Evangelische Verlagsanstalt.

Nida E A, Louw J P, Snyman A H, Cronje JvW 1983. Style and discourse. Cape Town: United Bible Societies.

O'Brien P T 1991. The Epistle to the Philippians. Michigan, Grand Rapids: WB Eerdmans.

Pelser G M M 1971. Die Carmen Christi Fil 2:6-11; 'n EksegetieseChristologiese ondersoek. Pretoria: Universiteit van Pretoria.

Schenk W 1984. Die Philipperbrief des Paulus. Kommentar. Stuttgart: W Kohlhammer. 
Silva M 1988. Philippians. The Wycliffe Exegetical Commentary (Ed. K Barker). Chicago: Moody Press.

Snyman A H 1979. "Filippense 2:6-11". In: Barkhuizen J H (red). Hymni Christiani. Supplementum HTS. Pretoria: Gutenburg Boekdrukkers, 4453.

Tolmie D F 2000a. "Paulus se retoriese strategie in Galasiërs 1:1-10. Acta Theologica 20(2), 122-137.

-, 2000b. "Enkele vertaalprobleme in die vertaling van die Filippensebrief in die 1983 - Afrikaanse vertaling". NGTT 41(2) \& (3), 217-227.

-, D F 2005. Persuading the Philippians. A Text-Centred Rhetorical Analysis of a Pauline Letter. WUNT 2/190. Tübingen: Mohr (Siebeck).

Vincent M R 1961. The Epistles to the Philippians and to Philemon. A critical and exegetical commentary. Edinburgh: T\&T Clark.

Watson D F 1988. "A Rhetorical Analysis of Philippians and its Implications for the Unity Question". Novum Testamentum 30, 57-88.

-, 1997. "The integration of epistolary and rhetorical analysis of Philippians", in: Porter S E \& Olbricht $\mathrm{T} \mathrm{H}$ (eds.), The rhetorical analysis of scripture. Essays from the 1995 London conference. JSNT. Sheffield: JSOT Press, 398-426. 